\title{
INFLUENCE OF FINANCIAL LITERACY, MANAGERIAL EXPERIENCE ON FINANCIAL MANAGEMENT PERFORMANCE OF SMES IN SURABAYA
}

\author{
Olivia Aurelia Heryanto ${ }^{1}$, Pwee Leng ${ }^{2}$ \\ 1,2 Finance and Investment Program, Faculty of Business and Economics, Petra Christian University \\ Jl. Siwalankerto 121-131, Surabaya \\ E-mail: ${ }^{1} \mathrm{~m} 37416052 @ j o h n . p e t r a . a c . i d ;{ }^{2}$ pweeleng@petra.ac.id
}

\begin{abstract}
This study aims to determine the effect of financial literacy and managerial experience on financial management performance of SMEs. The data collection technique in this study was using a questionnaire distributed to 400 SME owners in Surabaya. The data that has been collected is then processed by the logistic regression analysis method using the software IBM SPSS Statistics 25 . The results show that financial literacy and managerial experience variables significantly affect financial management performance variables.
\end{abstract}

Keywords: Financial Literacy, Managerial Experience, Financial Management Performance, SMEs.

\section{INTRODUCTION}

Micro, Small, and Medium Enterprises (MSMEs) play an important role in the Indonesian economy. This can be seen from the contribution of MSMEs to Indonesia's Gross Domestic Product (GDP), which is $60.34 \%$ and always increases every year (Kementerian Koordinator Bidang Perekonomian, 2018). Apart from being a contributor to GDP, the existence of MSMEs can also provide jobs for the people of Indonesia. This can be seen from data from the Ministry of Cooperatives and Small and Medium Enterprises (2017). MSMEs can absorb $97.02 \%$ of the national workforce or as many as $116,673,416$ people, with the numbers increasing every day. So, President Joko Widodo in the Ministry of Communication and Information Technology (2016) said that MSMEs are the backbone of the Indonesian economy.

East Java Province is the province with the highest number of MSMEs in Indonesia, which is $4,618,283$ business units and the city of Surabaya is the city with the largest number of MSMEs in East Java, which is 374,533 business units consisting of various industrial sectors (Central Bureau of Statistics, 2016). In addition, the existence of MSMEs also helps the economic development of the city of Surabaya. $98 \%$ of the economic growth in the city of Surabaya is supported by the MSME sector, while the rest is from large companies (Bangga Surabaya, 2018). However, behind this success, there are still many MSMEs in the city of Surabaya that are experiencing problems that can hinder the performance of their business financial management, such as limited working capital, inefficient management, and limited access to markets. This is because there are still many MSME owners in Surabaya who have low financial literacy (Kementerian Koperasi dan Usaha Kecil dan Menengah Republik Indonesia, 2017). MSME owners who do not have financial literacy result in a lack of information about access to capital and financial management (Siekei, Wagoki \& Kalio, 2013; Basana and Tarigan, 2021). Many MSMEs lack the eligibility to obtain credit loans and management capacity due to financial literacy. The low level of financial literacy of MSME owners makes creditors reluctant to lend funds to MSMEs because it is often found that MSME finances are not transparent and many MSMEs do not have financial reports, thus making MSMEs quite risky debtors (Siekei, Wagoki, \& Kalio, 2013).

Financial literacy is knowledge about finance that needs to be owned by MSME owners to improve the performance of business financial management (Wise, 2013; Saputra, et al., 2021). According to Siekei, Wagoki, \& Kalio (2013), financial literacy affects the decision-making process of business owners, such as timely bill payments and proper debt management to improve debtor creditworthiness, economic growth, reduce poverty, and use financial products and services more effectively. Furthermore, financial literacy helps to empower and educate MSME owners to use their knowledge to evaluate effects and make appropriate financial decisions. With financial literacy, most MSME owners can overcome problems related to business finance. In addition, financial literacy 
prepares MSME owners to face difficult economic times through risk-reducing strategies such as accumulating savings, diversifying assets, and buying business insurance (Siekei, Wagoki, \& Kalio, 2013).

In addition to financial literacy, managerial experience also affects financial management performance and effort (Wahono \& Pertiwi, 2020). Research conducted by Weterings \& Koster (2017) shows that organizational experience influences financial management performance. Managerial experience is the experience of business owners about managing a business that continues to grow during entrepreneurship (Shanthana \& Basana, 2020). Business owners who have a lot of managerial experience will be more careful in making decisions to avoid mistakes that have been experienced in the past so as not to harm the business that is being undertaken now. Business owners will also pay more attention to their business details and find it easier to innovate to maximize financial management performance business (Weterings \& Koster, 2017).

Based on the results of research conducted by Siekei, Wagoki, \& Kalio (2013), financial literacy affects the performance of MSME financial management. Similar analysis has also been applied in Surabaya and resulted in the same conclusion (Linawati, 2017; Saputra, et al., 2021). However, the two studies have not discussed the managerial experience variable. At the same time, the research conducted by Balsmeier \& Czarnitzki (2014) found that managerial experience also influences the financial management performance of MSMEs. Therefore, the researcher wants to know the effect of financial literacy and managerial expertise on Surabaya SMEs' financial management performance.

\section{LITERATURE REVIEW}

\section{Resources Based Theory}

Resource-Based Theory (RBT) looks at how a company's resources can help create a sustainable competitive advantage. According to Eniola \& Entebang (2017), SMEs use tangible and intangible resources as the basis for maintaining the ability to compete and produce superior company performance. Tangible resources consist of financial capital (equity capital, debt capital, retained earnings) and physical capital (for example, machinery and buildings). Meanwhile, intangible resources consist of entrepreneurial knowledge, skills, experience, organizational procedures, and reputation. These resources are described by resource-based theory as the company's characteristics in obtaining profits, experiencing growth, and then impacting the company's survival. The main objective of resource-based theory is that companies can achieve competitive advantage and experience superior growth and performance if the company can acquire and control existing resources and absorb and apply these resources to the company's operational activities (Almarri \& Gardiner, 2014). Experience and knowledge are also an essential part of resource-based theory because they provide time for business owners to identify opportunities, develop contacts and learn how to access and interact with funders, including bank managers and investors (Eniola \& Entebag, 2017).

\section{Financial Management Performance}

Performance is the result of a process that is measured over a certain period based on pre-agreed terms (Koerniawan \& Malelak, 2021). Financial management performance is the result that a business has achieved from managing business finances effectively during a certain period. SMEs need financial management performance because it can be used to determine and evaluate the level of success of SMEs based on financial activities (Rudianto, 2013). However, Aribawa (2016) states that two assumptions affect SME financial management performance measurement. The first assumption is that it is difficult to measure the performance of SMEs quantitatively due to the limited understanding of financial literacy from SME owners. The second assumption states that quantitative measurement of financial management performance is generally only appropriate if it is used to measure large companies whose company management is structured. Therefore, to make it easier for SME owners to calculate the financial management performance of their business, Aribawa 
(2016) states that financial management performance can be measured by looking at sales growth and gross profit growth.

\section{Financial Literacy}

Financial literacy is a person's level of understanding of financial concepts. As a result, they can manage finances wisely and make appropriate short-term and long-term financial decisions (Remund, 2010; Wahono, \& Pertiwi, 2020). According to Siekei, Wagoki, \& Kalio (2013), financial literacy can be measured using three indicators. These indicators include bookkeeping, credit management, and ability in economic analysis.

\section{Managerial Experience}

Managerial experience is part of human resources consisting of knowledge of technology, organization, and skills in business management acquired during entrepreneurship (Weterings \& Koster, 2007; Shanthana \& Basana, 2020). According to Kidwell \& Turrisi (2004), an SME owner needs to have managerial experience because the experience gained during entrepreneurship can help to have a better understanding of the business being run. Foster (2001), in his research, found that can be measured managerial experience by looking at the length of time SME owners have been entrepreneurship, the level of knowledge and skills regarding business management, and the level of mastery of work.

\section{Relationship Between Concepts}

\section{a. The Effect of Financial Literacy on Financial Management Performance of SMEs}

Financial literacy helps business owners to have the knowledge, skills, and abilities to make financial decisions. Business owners need financial literacy to assist in making business plans, financial plans, and investment decisions. The research results conducted by Agyapong \& Attram (2019) show that financial literacy significantly influences financial management performance. Financial literacy can assist SME owners in making decisions regarding budgeting and production costing, thereby reducing wasted costs caused by improper financial selection and management (Shuib et al., 2013). The right financial decisions will impact business growth and continuity, which will create profits for the business.

H1 : The Effect of Financial Literacy on Financial Management Performance of SMEs Financial

\section{b. The Effect of Managerial Experience on SME Financial Management Performance}

Managerial experience is essential for SME owners because it can help reduce the risk that can lead to failure in SMEs. For example, in the pastry business. SME owners who have a lot of experience know that the pastry business will be busy at the time of religious holidays so that before the holidays, SME owners will prepare stock and shop for raw materials. SME owners who have little experience tend to be impatient in receiving orders because they need money, so they set the price of materials according to the current price. The price of materials at the holiday may rise, or even the materials are not available because many other people are also looking for these materials. SME owners who have little experience can suffer losses. The above risks can be minimized if the SME owner has a lot of experience in the business he runs.

H2 : The Effect of Managerial Experience on SME Financial Management Performance Managerial

Based on the explanation in the literature review, it can be determined the hypotheses of this study in the research framework. 


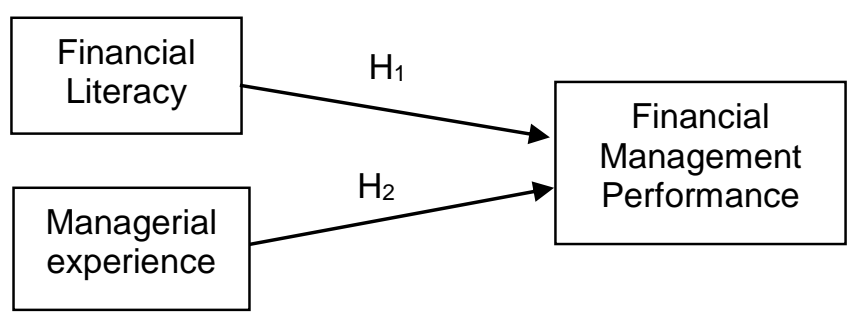

Figure 1. Research Framework

\section{METHODOLOGY}

This research is an associative type of research. This study examines the effect of financial literacy and managerial experience on financial management performance. The sample in this study is SMEs located in Surabaya with the following criteria: businesses that have annual sales of a minimum of Rp. 300,000,000 and a maximum of Rp. 50,000,000,000 (Law Number 20 of 2008 concerning SMEs). The data collection method used in this research is by distributing questionnaires through a google form. The data collection procedure was carried out by distributing questionnaires via the link google form and distributed through social media such as Instagram, Linkedln, Twitter, Line, and Whatsapp to family, friends, co-workers from the closest people. SMEs that researchers meet in their daily activities, which are then filtered using screening in the first part of the questionnaire.

\section{Variable Dependent $(Y)$}

\section{Concept : Financial Management Performance (Y)}

Operational definition : The result of business financial management over a certain period of time. Empirical Indicators : According to Aribawa (2016), to measure the financial management performance of SMEs using respondents' statements regarding Sales Growth \& Gross Profit Growth.

Independent Variable (X)
Concept
: Financial Literacy $(\mathrm{X} 1)$

Operational Definition: The level of understanding and knowledge of SME owners about finance to make decisions related to business financial management.

Empirical Indicators : According to Siekei, Wagoki, \& Kalio (2013), for financial literacy, SME owners use respondents' statements regarding: Bookkeeping, Credit Management, Financial Analysis.

Concept : Managerial Experience (X2)

Operational Definition: Experience in managing a business obtained by SME owners during entrepreneurship.

Empirical Indicators : According to Foster (2001), to measure the managerial experience of SME owners using respondents' statements regarding Level of knowledge and skills of SME owners \& Level of mastery of work

\section{ANALYSIS AND DISCUSSION}

The object of this research is SMEs located in the city of Surabaya. The questionnaire in this study was made using an application google form which was distributed on a platform social media to family, friends, colleagues from the closest people, and SMEs that the researchers met in their daily activities. The respondent's profile is divided based on the total turnover/sales per year, age, gender, type of business industry, the length of time the respondent has been an entrepreneur, and the hypothesis testing in Table 1.

Table 1. The Results of Hypothesis Test

\begin{tabular}{lcc}
\hline \multicolumn{1}{c}{ Effect Between Variables } & Sig. & Note \\
\hline Financial Literacy to Financial Management Performance & 0.000 & Reject H0 \\
Managerial Experience Financial Management Performance & 0.006 & Reject H0 \\
\hline
\end{tabular}


Based on Table 1, the results of hypothesis 1, the financial literacy has a significant effect on financial management performance SMEs, where the value of Sig. $0.000<0.050$ then reject H0, meaning that financial literacy (FL) has a significant effect on financial management performance (FMP). Hypothesis 2, managerial experience has a significant effect on financial management performance SMEs, where the value of Sig. ME $0.006<0.050$ then rejects H0, meaning that managerial experience (ME) has a significant effect on financial management performance (FMP).

Researchers also want to know whether, during the COVID-19 pandemic, there a change in the financial management performance of SMEs was with the same test, want to know whether financial literacy and managerial experience have a significant effect on the changes that occur.

Table 2. Financial Management Performance during the COVID-19 Pandemic

\begin{tabular}{lcc}
\hline Effect of Variables & Sig. & Note \\
\hline Financial Literacy Financial Management Performance & 0.000 & Reject H0 \\
Managerial Experience Financial Management Performance & 0.006 & Reject H0 \\
\hline
\end{tabular}

Based on Table 2, the first hypothesis, financial literacy has a significant effect on financial management performance SMEs, shows the value of Sig. FL $0.000<0.050$ then rejects $\mathrm{H} 0$, meaning that financial literacy (FL) has a significant effect on financial management performance (FMP) during the COVID-19 pandemic. The second hypothesis the managerial experience has a significant impact on financial management performance SMEs, where the value of Sig. ME $0.034<0.050$ then rejects $\mathrm{HO}$, meaning that managerial experience (ME) has a significant effect on financial management performance (FMP) during the COVID-19 pandemic. In this analysis, financial literacy is divided into two categories: high and low. Table 3 shows the results of crosstabulation from $88.5 \%$ of respondents who have high financial literacy as many as $81.3 \%$ of them have good financial management performance before the COVID-19 pandemic. Meanwhile, $11.5 \%$ of respondents with low financial literacy, $10.7 \%$ have poor financial management performance.

Table 3. Crosstabulation of Financial Literacy with Financial Management Performance before COVID-19

\begin{tabular}{ccccc}
\hline & & \multicolumn{3}{c}{ Financial Literacy } \\
\cline { 3 - 5 } & & Low & High & Total \\
\hline & Disagree & 43 & 29 & 72 \\
FMP Before COVID-19 & $\%$ & $10.7 \%$ & $7.2 \%$ & $18 \%$ \\
& Agree & 3 & 326 & 329 \\
& $\%$ & $0.7 \%$ & $81.3 \%$ & $82 \%$ \\
\hline TOTAL & & 46 & 355 & 401 \\
$\%$ & & $11.5 \%$ & $88.5 \%$ & $100 \%$ \\
\hline
\end{tabular}

Table 4. Crosstabulation of Financial Literacy with Financial Management Performance during COVID-19

\begin{tabular}{ccccc}
\hline & & \multicolumn{3}{c}{ Financial Literacy } \\
\cline { 3 - 5 } & & Low & High & Total \\
\hline & Disagree & 45 & 141 & 186 \\
FMP During COVID-19 & $\%$ & $11.2 \%$ & $35.2 \%$ & $46.4 \%$ \\
& Agree & 1 & 214 & 215 \\
& $\%$ & $0.2 \%$ & $53.4 \%$ & $53.6 \%$ \\
\hline TOTAL & & 46 & 355 & 401 \\
$\%$ & & $11.4 \%$ & $88.6 \%$ & $100 \%$ \\
\hline
\end{tabular}

Table 4 shows that $53.4 \%$ of respondents have high financial literacy, $53.1 \%$ of them have good financial management performance during COVID-19. Meanwhile, from $11.5 \%$ of respondents who have low financial literacy, $11.2 \%$ of them have poor financial management performance.

In this analysis, managerial experience is divided into a lot and a little. Based on table 5 , of the 82.5 respondents with a lot of managerial experience, $77.3 \%$ have good financial management 
performance. Meanwhile, $17.5 \%$ of respondents have little managerial experience, and $12.7 \%$ have poor financial management performance.

Table 5. Crosstabulation of Managerial Experience with Financial Management Performance before COVID-19

\begin{tabular}{ccccc}
\hline & & \multicolumn{3}{c}{ Managerial Experience } \\
\cline { 3 - 5 } & & Few & Many & Total \\
\hline & Disagree & 51 & 21 & \\
FMP Before COVID-19 & $72 \%$ & $12.7 \%$ & $5.2 \%$ & $18 \%$ \\
& Agree & 19 & 310 & 329 \\
& $\%$ & $4.7 \%$ & $77.3 \%$ & $82 \%$ \\
\hline TOTAL & & 70 & 331 & 401 \\
$\%$ & & $17.5 \%$ & $82.5 \%$ & $100 \%$ \\
\hline
\end{tabular}

Table 6. Crosstabulation of Managerial Experience with current Financial Management Performance COVID-19

\begin{tabular}{ccccc}
\hline & & \multicolumn{3}{c}{ Managerial Experience } \\
\cline { 3 - 5 } & & Few & Many & Total \\
\hline & Disagree & 69 & 117 & 186 \\
FMP When COVID-19 & $\%$ & $17.2 \%$ & $29.2 \%$ & $46.4 \%$ \\
& Agree & 1 & 214 & 215 \\
& $\%$ & $0.2 \%$ & $53.4 \%$ & $53.6 \%$ \\
\hline TOTAL & & 70 & 331 & 401 \\
$\%$ & & $17.4 \%$ & $82.6 \%$ & $100 \%$ \\
\hline
\end{tabular}

Based on Table 6, at the time of occurrence of COVID-19, from $82.5 \%$ of respondents who have a lot of managerial experience, $53.1 \%$ of them have good financial management performance. Meanwhile, from $17.5 \%$ of respondents who had a bad experience, $17.2 \%$ of them had poor financial management performance.

Based on the results of the crosstabulation above, it can be concluded that both before and during the COVID-19 pandemic, business owners who have high financial literacy tend to have good financial management performance. In contrast, business owners with low financial literacy tend to have poor financial management performance. Likewise, with managerial experience, respondents with a lot of managerial experience tend to have good financial management performance. Meanwhile, respondents with little managerial experience tend to have poor financial management performance.

Table 7. Crosstabulation of Length of Time in Entrepreneurship with Financial Management Performance during COVID-19

\begin{tabular}{ccccccc}
\hline & & \multicolumn{5}{c}{ Length of Time in Entrepreneurship } \\
\cline { 3 - 6 } & & $0-5$ Years & $6-10$ Years & $11-20$ Years & $>20$ Years & Total \\
\cline { 2 - 7 } & Disagree & 31 & 11 & 17 & 13 & 72 \\
FMP Prior & \%Column & $21.2 \%$ & $12.8 \%$ & $17.7 \%$ & $17.8 \%$ & $18 \%$ \\
COVID-19 & \%Total & $7.7 \%$ & $2.7 \%$ & $4.2 \%$ & $3.2 \%$ & $18 \%$ \\
& Agree & 115 & 75 & 79 & 60 & 329 \\
& \% Column & $78.8 \%$ & $87.2 \%$ & $82.3 \%$ & $82.2 \%$ & $82 \%$ \\
& $\%$ Total & $28.7 \%$ & $18.7 \%$ & $19.7 \%$ & $15 \%$ & $82 \%$ \\
\hline \multirow{6}{*}{ TOTAL } & 146 & 86 & 96 & 73 & 401 \\
& \% Column & $100 \%$ & $100 \%$ & $100 \%$ & $100 \%$ & $100 \%$ \\
& \% Total & $36.4 \%$ & $21.4 \%$ & $23.9 \%$ & $18.2 \%$ & $100 \%$ \\
\hline
\end{tabular}

Table 7 shows a total of 146 respondents who have been in entrepreneurship for $0-5$ years as many as $78.8 \%$ have financial management performance before the COVID-19 pandemic. Then, from a total of 86 respondents who have been in entrepreneurship for $6-10$ years, $87.2 \%$ have good financial management performance. In addition, out of 96 respondents who have been in entrepreneurship for $11-20$ years, $82.3 \%$ have good financial management performance. The rest, of the 73 respondents who have been in entrepreneurship for more than 20 years, $82.2 \%$ have good financial management performance. 
Table 8. Crosstabulation of Managerial Experience with Financial Management Performance during COVID-19

\begin{tabular}{ccccccc}
\hline & & \multicolumn{5}{c}{ Length of Time in Entrepreneurship } \\
\cline { 2 - 6 } & & $0-5$ Years & $6-10$ Years & $11-20$ Years & $>20$ Years & Total \\
\cline { 2 - 7 } & Disagree & 74 & 29 & 47 & 36 & 186 \\
& $\%$ Column & $50.7 \%$ & $33.7 \%$ & $49 \%$ & $49.3 \%$ & $46.4 \%$ \\
FMP During & $\%$ Total & $18.5 \%$ & $7.2 \%$ & $11.7 \%$ & $9 \%$ & $46.4 \%$ \\
COVID-19 & Agree & 72 & 57 & 49 & 37 & 215 \\
& $\%$ Column & $49.3 \%$ & $66.3 \%$ & $51.5 \%$ & $50.7 \%$ & $53.6 \%$ \\
\% Total & $18 \%$ & $14.2 \%$ & $12.2 \%$ & $9.2 \%$ & $53.6 \%$ \\
\hline TOTAL & 146 & 86 & 96 & 73 & 401 \\
$\%$ Column & $100 \%$ & $100 \%$ & $100 \%$ & $100 \%$ & $100 \%$ \\
$\%$ & $36.4 \%$ & $21.4 \%$ & $23.9 \%$ & $18.2 \%$ & $100 \%$ \\
\hline
\end{tabular}

Based on table 8 during the COVID-19 pandemic, it shows that out of a total of 146 respondents who have been in entrepreneurship for $0-5$ years, as many as $50.7 \%$ have good performance, poor business financial management. Then, from a total of 86 respondents who have been in entrepreneurship for 6-10 years, $66.7 \%$ have good financial management performance. In addition, from 96 respondents who have been in entrepreneurship for $11-20$ years, 51.5\% also have good financial management performance. The rest, from 73 respondents who have been in entrepreneurship for more than 20 years, $50.7 \%$ have good financial management performance.

\section{The Effect of Financial Literacy on Financial Management Performance}

Based on the analysis that has been carried out, it is found that financial literacy has a significant effect on the financial management performance of SMEs both before and during the COVID-19 pandemic. From the crosstabulation results, it was also found that $82 \%$ of SMEs had good financial performance before the COVID-19 pandemic, and $81.3 \%$ had high financial literacy. Likewise, during the COVID-19 pandemic, out of 53.4\% of SMEs had good financial management performance, $53.1 \%$ of them also had high financial literacy. SME owners who make financial reports and business budgets can find out the financial condition experienced by their business so that SME owners can control income and expenses and maximize the financial performance of their business. SME owners who have high financial literacy also understand and consider the financial condition of their business in advance to avoid default and access various financial sources because they have good financial performance. In addition, SME owners who have high financial literacy can also make good financial decisions because they can perform financial analyses.

In addition, the odds ratio during the COVID-19 pandemic resulted in a value of 26.637. This figure is quite far compared to the odds ratio value in the period before the COVID-19 pandemic, which was only 7.396. This can happen because, during the COVID-19 pandemic, SME owners are trying to improve their financial literacy, especially in the knowledge of credit. Credit or loans can be used as additional business capital when uncertain economic and market conditions. The results of this study are in line with research conducted by Agyapong \& Attram (2019) and Kidwell \& Turrisi (2004), which states that financial literacy has a significant effect on financial management performance.

\section{Effect of Managerial Experience on Financial Management Performance}

Based on the analysis that has been done, it was found that managerial experience has a significant effect on the financial management performance of SMEs both before and during the COVID-19 pandemic. The results of the crosstabulation test show that of the $82 \%$ of SMEs that had good financial performance before the COVID-19 pandemic, $77.3 \%$ of them had extensive (wide) managerial experience. Likewise, during the COVID-19 pandemic, out of 53.4\% of SMEs had good financial management performance, $53.1 \%$ of them also had a lot of experience. SME owners who have a lot of managerial experience have broader knowledge, skills, and mastery of business management than SME owners who have little experience. In addition, the experience of SME owners can also help to make decisions. For example, suppose an SME has previously experienced a failure that resulted in a loss. In that case, the SME owner can use that failure as analysis to develop to make business performance better. 
The results of the crosstabulation tables 4.23 and 4.24 show that SME owners who have been in business for 0-5 years had good financial management performance before the COVID-19 pandemic. Still, during the COVID-19 pandemic, they had poor financial management performance. Meanwhile, SME owners who have been in entrepreneurship for $6-10$ years, $11-20$ years, and more than 20 years have had good financial management performance before and during the COVID-19 pandemic. It can be concluded that SME owners who have been entrepreneurship for more than five years can manage and maintain their business financial management performance. SME owners with more managerial experience tend to be superior in analyzing opportunities, anticipating threats, and changing market conditions. The results of this study are in line with research conducted by Shuib et al. (2013), which found that managerial experience influences the financial management performance of SMEs.

\section{CONCLUSION AND RECOMMENDATIONS}

Based on the research results that have been done, it can be concluded. First, financial literacy has a significant effect on the financial management performance of SMEs in Surabaya. Second, managerial experience has a significant effect on the financial management performance of SMEs in Surabaya. Therefore, it is hoped that SME owners, both in Surabaya and other cities, can pay more attention to financial literacy. It especially regards financial reports and credit management by participating in training, seminars, and activities that can increase SME owners' knowledge, understanding, and skills. It can also be useful to enrich the managerial experience of SME owners, especially for SME owners who have been in entrepreneurship for 0 - 5 years and more than 20 years. The Surabaya City Government can improve and facilitate SME training related to financial literacy such as financial reports or on how to manage a business because it is an important factor in the survival of SMEs and because SMEs are one of the main pillars of the Surabaya City economy. For further researchers, this study has a population limitation because it only uses respondents from the city of Surabaya, so the results of this study cannot be generalized. Further researchers can examine a broader population of respondents.

\section{REFERENCES}

Agyapong, D., \& Attram, A.B. (2019). Effect of Owner-Manager's Financial Literacy on the Performance of Smes in the Cape Coast Metropolis in Ghana. Journal of Global Entrepreneurship Research, 9, 2-13

Almarri, K., \& Gardiner, P. (2014). Application of Resource-Based View to Project Management Research: Supporters and Opponents. Procedia - Social and Behavioral Sciences, 119, 437-445.

Aribawa. (2016). The Effect of Financial Literacy on the Performance and Sustainability of MSMEs in Central Java. E-Jurnal UAJY, 20(1), 1-13.

Central Bureau of Statistics. (2016). Number of Businesses/Companies by Region and Income/Turnover Group of East Java Province. Retrieved from the 2016 Economic Census: https://se2016.bps.go.id/umkumb/ index.php/site/tabel?tid $=45 \&$ wid $=3500000000$

Balsmeier, B., \& Czarnitzki, D. (2014). How Important is Industry Specific Managerial Experience for Innovative Firm Performance?. ZEW Discussion Papers, 14-011.

Bangga Surabaya. (2018). Mayor Risma: 98 Percent of the Economy in Surabaya Comes from SMEs. Retrieved from https://humas.surabaya.go.id/2018/03/08/wali-kota-risma-98-persen-ekonomi-di-surabayaberasal-dari-pelaku-ukm/

Basana, S.R., \& Tarigan, Z.J.H. (2021). The Effect of Essential Information and Disposition Effect on Shifting Decision Investment. Accounting 8(2), 264-276, 10.5267/j.ac.2021.6.015.

Eniola, A.A., \& Entebang, H. (2017). SME Managers and Financial Literacy. Global Business Review, 18(3), 1-18.

Foster, B. (2001). Coaching for Employee Performance Improvement. PPM. Jakarta

Kementerian Koordinator Bidang Perekonomian. (2018). UMKM Sumbang 60 Persen ke Pertumbuhan Ekonomi Nasional. Liputan6. Retrieved from https://www.liputan6.com/ bisnis/read/3581067/umkm-sumbang60-persen-ke-pertumbuhan-ekonomi-nasional

Kementerian Koperasi dan Usaha Kecil dan Menengah Republik Indonesia. (2017). Perkembangan Data Usaha Mikro, Kecil, Menengah (UMKM) dan Usaha Besar (UB) Tahun 2016 - 2017. Retrieved from http://www.depkop.go.id/uploads/laporan /1549946778_UMKM\% 202016-2017\%20rev.pdf

Kidwell, B., \& Turrisi, R. (2004). An Examination of College Student Money Management Tendencies. Journal of Economic Psychology, 25(5), 601-616. https://doi.org/10.1016/S0167-4870(03)00073-4 
Koerniawan, S. A., \& Malelak, M. I. (2021). The Influence of Female Director on the Probability of Companies Experiencing Financial Distress. International Journal of Financial and Investment Studies, 1(2), $101-108$. https://doi.org/10.9744/ijfis.1.2.101-108

Linawati. (2018). The Influence of Financial Literacy and Family Relationships on the Growth of Micro, Small and Medium Enterprises. Surabaya: Petra Christian University.

Remund, D. L. (2010). Financial literacy explicated: the case for a clearer definition in an increasingly complex economy. The Journal of Consumer Affairs, 44 (2), 276-295

Rudianto. (2013). Information Management Accounting for Strategic Decision Making. Jakarta: Erlangga.

Saputra, J., Astuti, D., \& Pertiwi, D. (2021). Effect of Financial Literacy, Risk Attitude and Saving Motives to Disposition Bias on Mutual Funds Investors. International Journal of Financial and Investment Studies, 2(1), 27-33. https://doi.org/10.9744/ijfis.2.1.27-33

Shanthana L.S., \& Basana, S. R. (2020). Pengaruh Firm Size terhadap Leverage pada Perusahaan Manufaktur Publik Indonesia Periode 2013-2017. International Journal of Financial and Investment Studies, 1(1), 53-66. https://doi.org/10.9744/ijfis.1.1.53-66.

Shuib, N., Said, J., \& Atan, R. (2013). The Influence of Financial Management Practices, Board Effectiveness and Accountability towards Performance: Empirical Test of Non-Profit Organizations. Asia-Pacific Management Accounting Journal, 8(1), 43-63.

Siekei, J., Wagoki, J., \& Kalio, A. (2013). An Assessment of the role of Financial Literacy on Performance of Small and Micro Enterprises: Case of Equity Group Foundation Training Program on MSES in Njoro district Kenya. Journal of Economics \& Finance, 1(7), 250-336.

Wahono, H. K. \& Pertiwi, D. (2020). Pengaruh Financial Literacy, Materialism, Compulsive Buying Ttrhadap Propensity to Indebtedness. International Journal of Financial and Investment Studies, 1(1), 1-14. https://doi.org/10.9744/ijfis.1.1.1-14.

Weterings, A., \& Koster, S. (2017). Inheriting Knowledge and Sustaining Relationships: What Stimulates the Innovative Performance of Small Software Firms in the Netherlands?. Research Policy 36, 320-335.

Wise, S. (2013). The Impact of Literasi Keuangan on New Venture Survival. International Journal of Business and Managemen, 8(23), 30-39. 